\title{
Sublethal toxicity of organophosphate, diazinon on some organs of great sturgeon (Huso huso)
}

\author{
HA Khoshbavar-Rostami ${ }^{1}$, I Sharifpour ${ }^{2}$, A Mokarami-Rostami ${ }^{3}$ \\ ${ }^{1}$ Inland Waters Aquatic Stocks Research Center, Gorgan, Iran \\ ${ }^{2}$ Iranian Fisheries Research Organization, Tehran, Iran \\ ${ }^{3}$ The Caspian Sea Ecology Research Center, Sari, Iran
}

\begin{abstract}
Received: March 2014
Abstract

Sublethal toxicity effects of diazinon on the structure of some organs of great sturgeon (Huso huso) were investigated. Diazinon was applied at a sublethal concentration of $1.5 \mathrm{mg} \mathrm{L}^{-1}$ at $22 \pm 1{ }^{\circ} \mathrm{C}$ for nine weeks as a constant bath. Tissues of liver, kidney and gills were sampled and examined histopathologically after 1, 14, 28, 42 and 63 days post exposure to the toxicant. The results of light microscopic examinations of tissues revealed congestion of blood vessels, pyknosis and cloudy swelling in hepatocytes. Congestion of blood vessels and thickening of the basal membrane of bowman capsule in glumerol of the kidney were also observed. The gill of fish exposed to toxicant also showed congestion and dilation of blood vessels, swelling of the basement membrane, hyperplasia, fusion and necrosis of lamellae. This data showed that a long term exposure of fish to diazinon can cause several pathological changes in respiratory organ, haematopoietic tissues and liver.
\end{abstract}

Keywords: diazinon, great sturgeon, sublethal toxicity, histopathology.

\section{Introduction}

The progressive growth of anthropogenic pressures on the coastal and marine ecosystems has caused a remarkable increase in the level of contamination in the Caspian Sea. The main sources of such pollution are land-based/offshore sources and diazinon in

Correspondence I Sharifpour, Iranian Fisheries Research Organization, Tehran, Iran (e-mail: isharifpour@yahoo.com)
Accepted: August 2014

large quantities is one of the major herbicidal, insecticide and fish antiparasite chemicals currently used in these areas. Diazinon [O-O-diethyl O-(2-isopropyl-1-6-methyl-4-pryimidinyl) hosphorothioate] is an organophosphorus pesticide that is extensively used, both in agriculture and households to control insects in plants, fruit and vegetable crops (Dutta \& Meijer 2003), as well as nematodes and soil insects in lawns and croplands (Eisler 1986). After its application on crops and plants, diazinon is easily washed into surface waters and enters the ground water. Finally, it enters the aquatic environments in large quantities (Coppage \& Mathews 1974). Diazinon can cause severe pathological changes if aquatic animals are continuously in contact with chronic and long sublethal concentrations of diazinon. Such pathological damages can be dominant, particularly if the exposure period occurs under water quality parameters of low temperature, low moisture, high alkalinity and lack of suitable microbial degraders (Hamm, Wilson \& Hinton 1998). Diazinon LC $_{50}$ values vary widely and depend on the organism's age, weight and water quality conditions. Sublethal doses may lead to reduced growth and reproduction in aquatic invertebrates (Eisler 1986). In fishes, exposure to diazinon in sublethal doses is known to affect the nervous system by inhibition of acetylcholinesterase activity (Pan \& Dutta 1998; Dutta $\&$ Arends 2003), to cause abnormalities in the gills ( Dutta, Munshi, Roy, Singh, Adhikari \& Killius 1996; Sharifpour, Pourgholam, Soltani, Hassan, Akbari \& Nouri 2006), changes in the immune system (Dutta et al. 1996; Khoshbavar Rostami, Soltani \& Hassan 2006), to reduce the olfactory functioning (Moor \& Waring 1996), to disrupt ovarian structure (Dutta \& Maxwell 2003) and reduction in size and 
diameters of the lumen of seminiferous tubules and germ cells (spermatogonia) (Dutta \& Meijer 2003). Sturgeons are among the aquatic organisms that are severely influenced by the pollution impacts. The great sturgeon (also named beluga, giant sturgeon) (Huso huso) is the major economical species of northern part of Iran. This fish plays a significant role in the source income of the Iranian south Caspian Sea fisheries. These commercially valuable species of fish generally spend their adult lives in both freshwater and salt water environments with spawning in upriver. The main aim of this study was to determine whether sublethal toxicity of diazinon has significant histopathologic effects on the organs of gill, liver and kidney of great sturgeon (Huso huso).

\section{Materials and Methods}

\section{Fish}

One hundred fish weighing $450 \pm 50 \mathrm{~g}$ from Rajai Fish Farm in Mazandran province were used. Fish were held in $2000 \mathrm{~L}$ tanks containing 25 fish per tank at $22 \pm 1{ }^{\circ} \mathrm{C}$, dissolved oxygen of $7.5-9 \mathrm{mg} \mathrm{L}^{-1}$ and $\mathrm{pH}$ 7.5. Other water quality parameters including ammonia, nitrite and total hardness were $<0.02$ $\mathrm{mg} \mathrm{L}{ }^{-1},<0.1 \mathrm{mg} \mathrm{L}^{-1}$ and $145 \mathrm{mg} \mathrm{L}^{-1}$, respectively. Fish were acclimatized to the new conditions a few weeks prior to the experiments. Fish were fed with commercial trout pellet containing 50\% fish meal.

\section{Application of diazinon}

Fish were divided into two groups with each group containing 50 fish. Diazinon was applied to the water at a sublethal concentration of $1.5 \mathrm{mg} \mathrm{L}^{-1}$ at $22 \pm 1$ ${ }^{\circ} \mathrm{C}$ for 9 weeks as a constant bath (Khoshbavar Rostami et al. 2006). To maintain the toxicant concentration during the experiment, whole water in each tank was replaced with fresh diazinon treated water (1.5 $\left.\mathrm{mg} \mathrm{L}^{-1}\right)$ every $12 \mathrm{~h}$. Control fish were kept in the same system separately with water replacement every $12 \mathrm{~h}$.

\section{Collection and processing of samples}

Samples were collected from both groups after 24 $\mathrm{h}$ and thereafter every week until 9 weeks post-exposure to the toxicant. Five fish per treatment were sampled at each sampling time.

\section{Histopathological study}

Tissues of gills, liver and kidney were sampled for each treatment at each sampling time. Tissues were immediately fixed in cold $10 \%$ buffered formalin for at least $24 \mathrm{~h}$ before processing. The fixed tissues were processed in an automatic tissue processor using standard procedure (Roberts 2001). The paraffin embedded tissues were sectioned $(5 \mu \mathrm{m})$ using a Rotary Microtome. The sections were then stained using Hematoxylin and Eosin staining, mounted and examined under compound microscope. The indices below were used to show the severity of the lesions in the tissues:

- = no significant microscopic changes

$+=$ mild changes $(10$ percent change in $40 \mathrm{x}$ objective microscope view)

$++=$ moderate changes $(20$ percent change in $40 \mathrm{x}$ objective microscope view)

$+++=$ severe changes (more than 20 percent change in $40 \mathrm{x}$ objective microscope view)

\section{Results}

\section{Liver}

Congestion of blood vessels and sinus dilation were seen almost in all samples (Table 1). Different stages of degeneration leading to complete necrosis of hepatocytes, cytoplasmic degeneration, pyknotic nuclei, vacuolation in hepatic cells and rupture of

Table 1 Histopathological scores of great sturgeon liver exposed to continuous exposure of diazinon at $1.5 \mathrm{mg} \mathrm{L}^{-1}$ at 20 $22^{\circ} \mathrm{C}$ for 9 weeks

\begin{tabular}{|c|c|c|c|c|c|}
\hline \multirow[t]{2}{*}{ Histopathological changes } & \multicolumn{5}{|c|}{ Sampling days (post-exposure) } \\
\hline & 1 & 14 & 28 & 42 & 63 \\
\hline $\begin{array}{l}\text { Congestion of blood ves- } \\
\text { sels }\end{array}$ & +++ & +++ & ++ & + & + \\
\hline Hemorrhage & + & - & - & - & - \\
\hline Sinus dilation & - & - & + & ++ & ++ \\
\hline $\begin{array}{l}\text { Vacuolar degeneration of } \\
\text { hepatocytes }\end{array}$ & + & - & - & - & - \\
\hline Pyknosis of hepatic cells & + & +++ & + & + & + \\
\hline Cloudy swelling & - & +++ & - & - & - \\
\hline Focal necrosis & - & + & - & - & + \\
\hline $\begin{array}{l}\text { General necrosis of hepato- } \\
\text { cytes }\end{array}$ & - & - & + & + & - \\
\hline
\end{tabular}


Table 2 Histopathological scores of great sturgeon kidney exposed to continuous exposure of diazinon at $1.5 \mathrm{mg} \mathrm{L}^{-1}$ bath at $20-22^{\circ} \mathrm{C}$ for 9 weeks

\begin{tabular}{|c|c|c|c|c|c|}
\hline \multirow[t]{2}{*}{ Histopathological changes } & \multicolumn{5}{|c|}{ Sampling days (post-exposure) } \\
\hline & 1 & 14 & 28 & 42 & 63 \\
\hline $\begin{array}{l}\text { Congestion of blood ves- } \\
\text { sels }\end{array}$ & + & - & - & - & - \\
\hline Hemorrhage & - & - & - & - & - \\
\hline Cellular infiltration & + & - & - & - & - \\
\hline Congestion of glummerul & +++ & - & - & - & - \\
\hline $\begin{array}{l}\text { Vacuolar degeneration of } \\
\text { kidney cells nuclei }\end{array}$ & - & + & - & - & - \\
\hline $\begin{array}{l}\text { General necrosis of kid- } \\
\text { ney tissue }\end{array}$ & - & +++ & - & + & + \\
\hline Degeneration of tubules & - & - & + & - & - \\
\hline $\begin{array}{l}\text { Necrosis of kidney glum- } \\
\text { merul }\end{array}$ & - & - & + & - & - \\
\hline $\begin{array}{l}\text { Thicken of basal mem- } \\
\text { brane of bowman capsule }\end{array}$ & - & - & ++ & - & - \\
\hline $\begin{array}{l}\text { Pyknosis of different types } \\
\text { of kidney cells nuclei }\end{array}$ & - & + & - & + & + \\
\hline
\end{tabular}

Table 3 Histopathological scores of great sturgeon gill exposed to continuous exposure of diazinon at $1.5 \mathrm{mg} \mathrm{L}^{-1}$ at $20-22^{\circ} \mathrm{C}$ for 9 weeks

\begin{tabular}{|c|c|c|c|c|c|}
\hline \multirow[t]{2}{*}{ Histopathological changes } & \multicolumn{5}{|c|}{ Sampling days (post-exposure) } \\
\hline & 1 & 14 & 28 & 42 & 63 \\
\hline Congestion & + & - & ++ & - & - \\
\hline Dilation of blood vessels & - & - & - & - & - \\
\hline Mild cellular infiltration & - & - & - & - & - \\
\hline $\begin{array}{l}\text { Swelling of the basement } \\
\text { membrane }\end{array}$ & - & - & ++ & - & - \\
\hline $\begin{array}{l}\text { Increasing in lymphocytes } \\
\text { number }\end{array}$ & - & + & - & - & - \\
\hline $\begin{array}{l}\text { Separating and sloughing } \\
\text { of basement membrane }\end{array}$ & - & + & - & - & - \\
\hline Necrosis of lamellae & - & +++ & +++ & +++ & +++ \\
\hline $\begin{array}{l}\text { Hyperplasia and fusion of } \\
\text { lamellae }\end{array}$ & - & - & + & - & - \\
\hline Fusion of lamellae & - & - & - & ++ & ++ \\
\hline $\begin{array}{l}\text { Sloughing of basement } \\
\text { membranes of lamella }\end{array}$ & - & - & - & ++ & ++ \\
\hline Necrosis of lamellae & - & +++ & +++ & +++ & +++ \\
\hline
\end{tabular}

-vessels were also seen in the fish exposed to the toxicant. No pathological abnormalities were observed in the control group (Fig. 1).

\section{Kidney}

As shown in Table 2, congestion and hemorrhage were observed in the early times of exposure of fish to the toxicant. Tubular and haematopoietic cells degeneration, vacuolation, pyknosis and karyolysis of nuclei, necroses of the kidney haematopoietic tissue and to some extent, cellular infiltration in intercellular spaces of the tissue were also observed in kidney sections of fish exposed to diazinon, while no pathological changes were found in control fish (Fig. 2).

\section{Gills}

Histopathological changes in gills of fish exposed to the toxicant are shown in Table 3 and Figure 3. Congestion and dilation of blood vessels and swelling, separating and sloughing of basement membrane of the secondary lamella were the most common degenerative changes observable in the fish exposed to diazinon. After 28 days of exposure to the toxicant signs of hyperplasia, fusion and necrosis of lamellae were the more severe pathological findings (Fig. 3). The degree of histopathological changes was varied and time-dependent. No abnormality was found in the gill sections of control group.

\section{Discussion}

Exposure to diazinon produced remarkable alterations in the microscopic structure of the liver, kidney and gill of the great sturgeon. The pathological changes observed are not pathogonomic for organophosphorus poisoning but are similar to those produced by other pesticides. Cytoplasmic vacuolation, pyknosis, degeneration and necrosis of hypatocytes, hemorrhage, congestion of blood vessels and sinus dilation were observed in the liver tissue. The hepatocytes have undergone different stages of degeneration leading to complete necrosis after a longer exposure period to the toxicant. Therefore, the severity of some microscopic changes was time-dependent. Also, such changes in hepatocytes showed that these cells were quite sensitive to diazinon. Similar histopathological findings were also reported by Rahman, Hossain, Mollah \& Ahmad (2002) and Sharifpour et al. (2006) when Anabas testudineus, Channa punctatus and Barbodes gonionotus were exposed to diazinon for a short and/or 

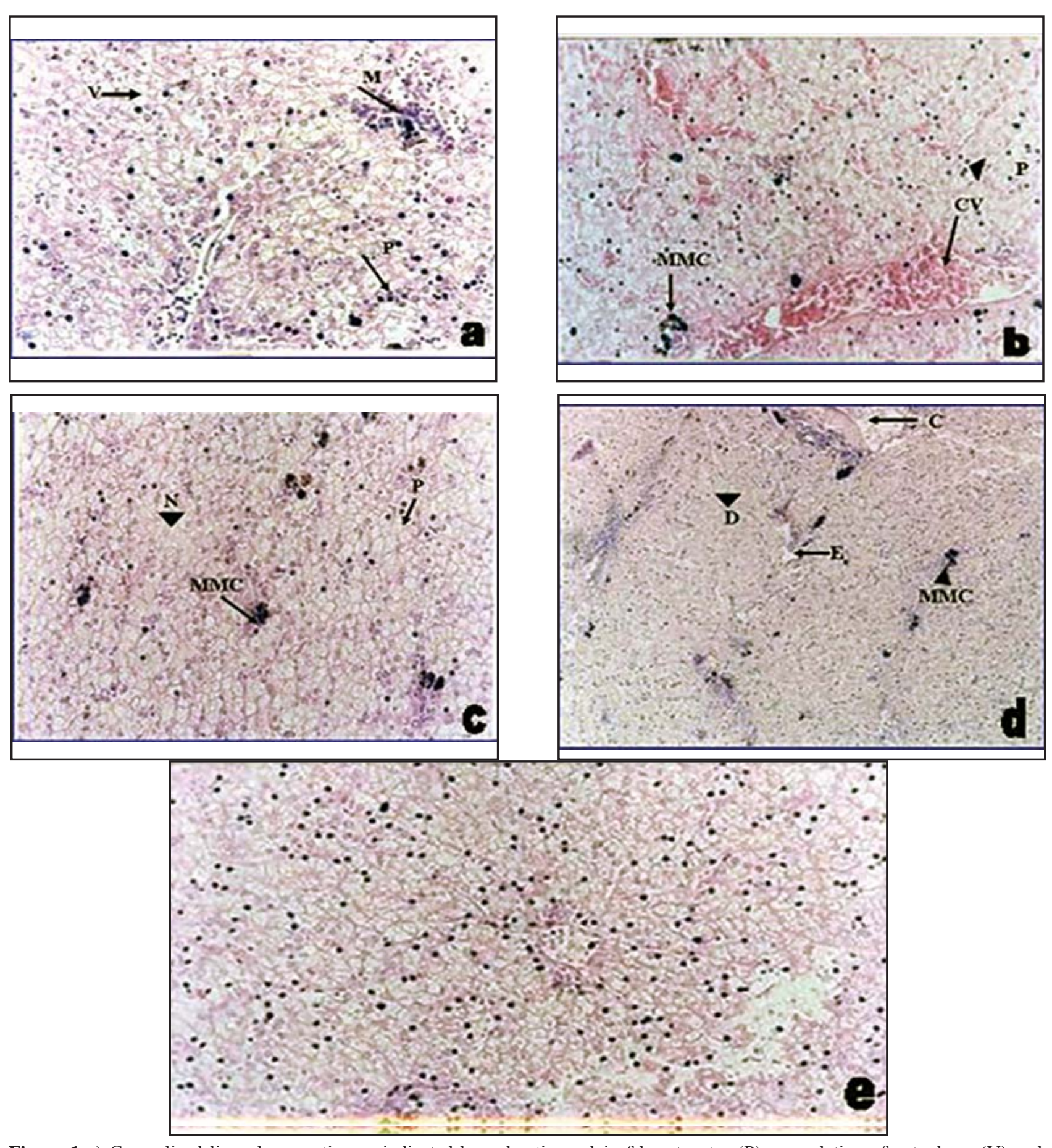

Figure 1 a) Generalized liver degeneration as indicated by pyknotic nuclei of hepatocytes (P), vacuolation of cytoplasm (V) and melanomacrophage centre (MMC) in fish exposed to $1.5 \mathrm{mg} \mathrm{L}^{-1}$ diazinon at 1 day post-exposure (H \& E, x 1075). b) Liver 15 days post exposure to $1.5 \mathrm{mg} \mathrm{L}^{-1}$ diazinon in great sturgeon. Pyknotic nuclei of hepatocytes $(\mathrm{P})$, congestion of blood vessel $(\mathrm{CV})$ and melanomacrophage centre (MMC), (H \& E, x 860). c) 28 days post exposure to $1.5 \mathrm{mg} \mathrm{L}^{-1}$ diazinon in liver of great sturgeon as indicated by pyknotic nuclei of hepatocytes (P), necrosis of liver tissue (N) and melanomacrophage centre (MMC) (H \& E, x 860). d) 42 days post exposure to $1.5 \mathrm{mg} \mathrm{L}^{-1}$ diazinon in liver of great sturgeon as indicated by expansion of sinusoid (E), congestion of vessel (C), degeneration of hepatocytes (D) and melanomacrophage centre (MMC) (H \& E, x 344). e) Liver 63 days post exposure to $1.5 \mathrm{mg} \mathrm{L}^{-1}$ diazinon in great sturgeon indicated by increased number of melanomacrophage centre, degeneration of hepatocytes, pyknosis and necrosis of hepatocytes and rupture of liver tissue (H \& E, x 860).

a long time period.

Degeneration and thinning of epithelial lining of the lamellae, hyperplasia, fusion and necrosis of lamellae, separation of vascular layer from the epi- 


\section{Iranian Journal of Aquatic Animal Health}
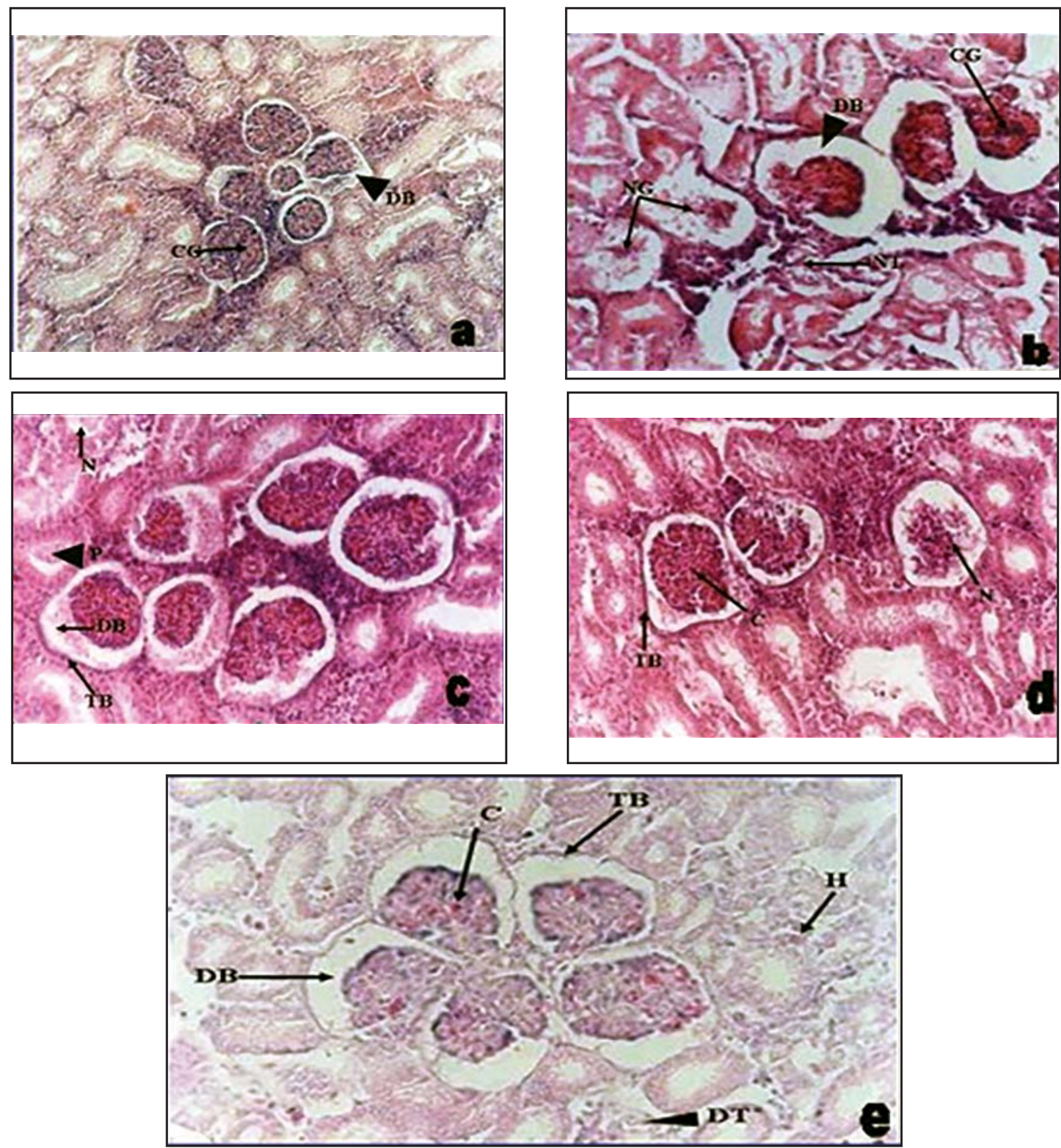

Figure 2 a) Congestion of glomerulus (CG) and dilation of Bowman's capsule (DB) in tissue of kidney at 1 day post-exposure to 1.5 $\mathrm{mg} \mathrm{L}^{-1}$ diazinon ( $\left.\mathrm{H} \& \mathrm{E}, \mathrm{x} 860\right)$. b) Congestion of glomerulus (CG), dilation of Bowman capsule (DB), necrosis of glomerulus (NG) and necrosis of tubules (NT) in tissue of kidney at 15 day post-exposure to $1.5 \mathrm{mg} \mathrm{L}^{-1}$ diazinon (H \& E, x 860). c) Thickening of basal membrane of Bowman's capsule (TB), dilation of Bowman's capsule (DB), necrosis of glomerulus (NG) and protein deposition in tubule $(\mathrm{P})$ in tissue of kidney at 28 days post-exposure to $1.5 \mathrm{mg} \mathrm{L}^{-1}$ diazinon (H \& E, x 752). d) Thickening of basal membrane of Bowman's capsule (TB), necrosis of glomerulus (NG) and congestion of glomerulus (CG) in tissue of kidney at 42 days post-exposure to $1.5 \mathrm{mg} \mathrm{L}^{-1}$ diazinon (H \& E, x 860). e) Thickening of basal membrane of Bowman's capsule (TB), dilation of Bowman's capsule (DB), degeneration of tubules (DT), hemorrhage of kidney $(\mathrm{H})$ and congestion of glomerulus (C) in tissue of kidney at 63 days post-exposure to $1.5 \mathrm{mg} \mathrm{L}^{-1}$ diazinon (H \& E, x 860).

thelium, and in some cases fusion of the epithelium of the adjacent villi were the conspicuous signs ob- servable in the gill sections. Furthermore, disruption and sloughing of respiratory epithelium from 

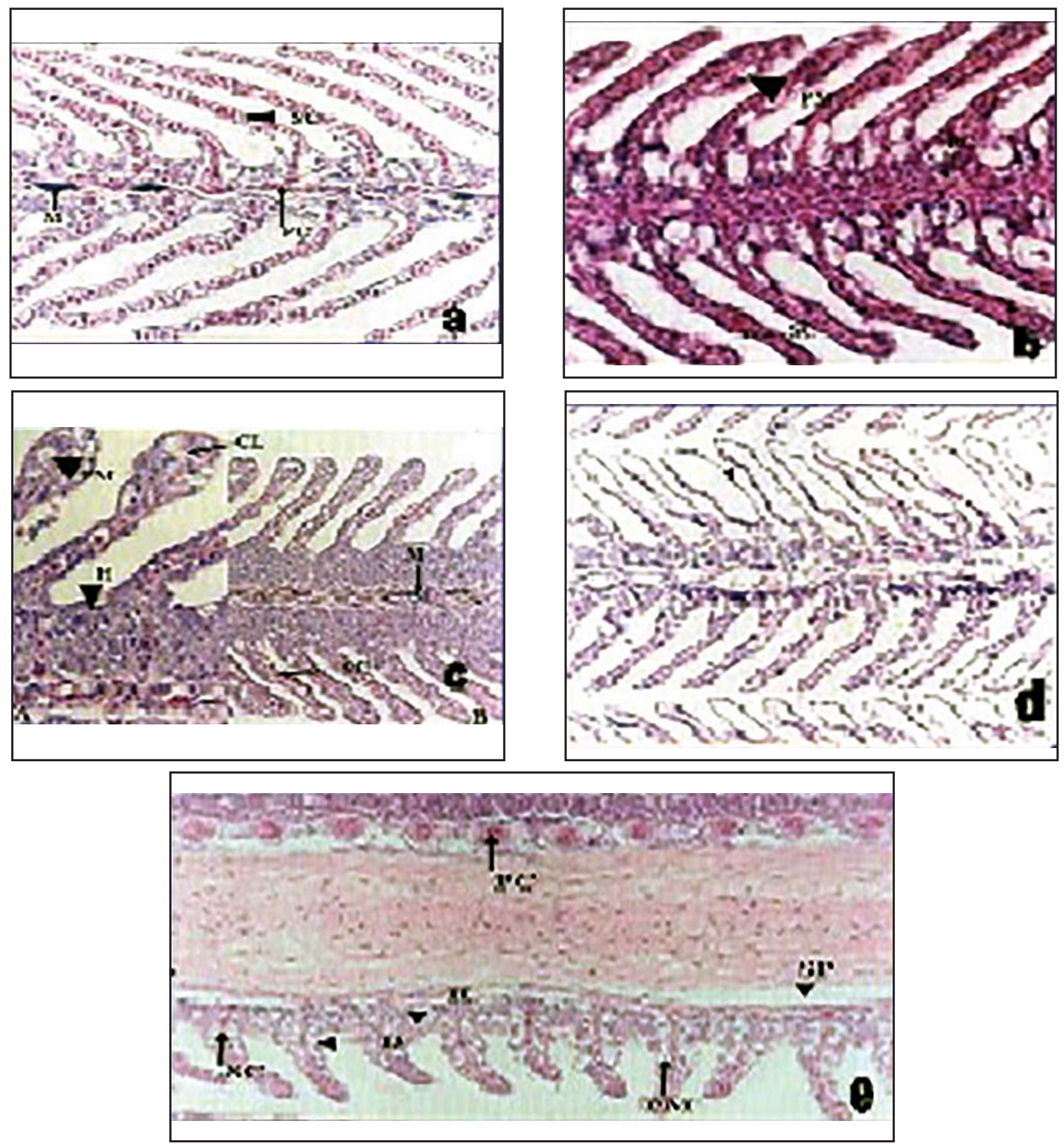

Figure 3 a) Gill lamellae of great sturgeon at 1 day post-exposure to $1.5 \mathrm{mg} \mathrm{L}^{-1}$ diazinon showing mild congestion of secondary lamellae (SC), congestion of primary lamellae (PC) and presence of melanin in blood vessel (M), (H \& E, x 1075). b) Gills lamellae of great sturgeon at 14 days post-exposure to $1.5 \mathrm{mg} \mathrm{L}^{-1}$ diazinon showing congestion of secondary lamellae (SC), congestion of primary lamellae (PC) and proliferation of mucus cells in secondary lamellae (PM) (H \& E, x 860). c) Gills lamellae of great sturgeon at 28 days post-exposure to $1.5 \mathrm{mg} \mathrm{L}^{-1}$ diazinon showing clubbing of secondary lamellae (CL), Hyperplasia (H), proliferation of mucus cells in secondary lamellae (PM) (picture A in C) and presence of melanin in blood vessel (M), congestion of secondary lamellae (SC) (picture B in C) (H \& E, A x 537 and B x 430). d) Gills lamellae of great sturgeon at 42 days post-exposure to $1.5 \mathrm{mg} \mathrm{L}^{-1}$ diazinon showing separation of epidermis from the base of secondary lamellae (arrow head). (H \& E, x 677). e) Gills lamellae of great sturgeon at 42 days post-exposure to $1.5 \mathrm{mg} \mathrm{L}^{-1}$ diazinon showing congestion of secondary lamellae (SC), congestion of primary lamellae (PC), dilation of secondary lamellae (D), proliferation of mucus cells in secondary lamellae (PM), hyperplasia $(\mathrm{H})$ and separation of epidermis from the base of primary lamellae (SP). (H \& E, x 677).

the basement membrane of gills in response to dia-

zinon have been reported in other species fish (Dut- 
ta, Richmonds \& Zeno 1993; Rahman et al. 2002; Sharifpour et al. 2006). Skidmor \& Tovel (1972) believed that lifting and swelling of the epithelium serve to increase the distance through which chemical irritants must diffuse to reach the bloodstream. However, Jagoe \& Haines (1983) reported that this could adversely affect oxygen uptake by increasing the distances over which respiratory diffusion occurs. Hyperplasia, fusion and necrosis of lamellae which were seen in this study have also been reported by previous researchers. Similar histopathological changes in gills of Bluegill sunfish (Lepomis macrohirus) exposed to diazinon have been reported. They reported that diazinon concentrations used in their experiments caused various types of changes, such as lifting of the epithelial layer, hyperplasia and necrosis, lamellar fusion, epithelial rupture, as observed in the present study. Dutta et al. (1993) believed that the microstructural changes in the affected cells might serve as a defense mechanism in protecting the fish from diazinon-contaminated water by increasing the diffusion distance. If the diffusion distance and secretion of mucus increase, it could affect the respiration of the fish, leading to its death. Also, Mallatt (1985) and Pourgholam (2005) demonstrated that gill alterations such as necrosis and rupture of lamellae are poisoning dose-dependent. Observation of congestion and hemorrhage in kidney tissue in the early times of exposure could be due to the diazinon effect on the blood vessels resulting in diapedes of blood vessels because no abnormalities were seen in the control fish. Also, pathological changes including tubular and haematopoietic cells degeneration, vacuolation, pyknosis and karyolysis of nuclei, necrosis of immunocompetent cells and cellular infiltration in tissue intercellular spaces were observed in the kidney sections of only the experimental fish. Similar histopathological changes were also reported by Rahman et al. (2002) and Sharifpour et al. (2006) when other fish were exposed to different concentrations of diazinon. Similar to liver and gill tissues the severity of some pathological changes in kidney sections was also time-dependent.

In conclusion, long term exposure of great sturgeon to diazinon can cause several pathological changes in respiratory organ, haematopoietic tissues and liver causing morbidity and mortality in fish. Therefore entrance of such chemical toxicant to Caspian Sea, the main natural source of this species, should be avoided.

\section{Acknowledgments}

We are grateful to professor M. Soltani, department of aquatic animal health, university of Tehran for guidance to this manuscript.

\section{References}

Coppage D.C. \& Matthew E. (1974) Short term effects of organophosphate pesticide on cholinesterases of estuarine fishes and pink shrimp. Bulletin of Environmental Contamination and Toxicology 32, $483-488$.

Dutta H.M., Richmonds C.R. \& Zeno T. (1993) Effects of diazinon on the gills of bluegill sunfish Lepomis macrochirus. Journal of Environmental Pathology, Toxicology and Oncology 12, 219 - 227.

Dutta H.M., Munshi J.S.D., Roy P.K., Singh N.K., Adhikari S. \& Killius J. (1996) Ultrastructural changes in the respiratory lamellae of the catfish, Heteropneustes fossilis, after sublethal exposure to malathion. Environmental Pollution 92, $329-341$.

Dutta H.M. \& Meijer H.J.M. (2003) Sublethal effects of diazinon on the structure of the testis of bluegill, Lepomis macrochirus, a microscopic analysis. Environmental Pollution 125, 355 - 360.

Dutta H.M. \& Arends D. (2003) Effect of endosulfan on brain, acetylcholinesterase activity in juvenile bluegill sunfish. Environmental Research 91, 157-162.

Dutta H.M. \& Maxwell L. (2003) Histological examination of sublethal effects of Diazinon on ovary of Bluegill, Lepomis macrochirus. Environmental Pollution 121, 95-102.

Eisler R. (1986) Diazinon hazard to fish. Wildlife and in- 
vertebrates: A synoptic review. U.S. Fish Wildlife Service and Biological Report, 85 (1.9): 37.

Hamm J.T., Wilson B.W. \& Hinton D.E. (1998) Organophosphate induced acetylcholine esterase inhibition and embryonic retinal cell necrosis in vivo in the teleost (Oryzias latipes). Neurotoxicology 19, 853 - 870.

Jagoe H. \& Haines T.A. (1983) Alterations in gill epithelial morphology of yearling Sunapee trout exposed to acute acid stress. Transaction of American Fishery Sciences 112, $689-695$

Khoshbavar-Rostami H.A., Soltani M. \& Hassan H.M.D. (2006) Immune response of great sturgeon (Huso huso) subjected to long-term Exposure to sublethal concentration of the organophosphate, Diazinon. Aquaculture 256, $88-94$.

Mallatt J. (1985) Fish gill structural changes induced by toxicants and other irritants: a statistical review. Canadian Journal of Fishery and Aquatic Sciences 42, 630 - 648.

Moore A. \& Waring C.P. (1996) Sublethal effects of the Pesticide diazinon on olfactory function in mature male, Atlantic salmon parr. Journal of Fish Biology 48, 758 - 775.

Pan G. \& Dutta H.M. (1998) The inhibition of brain acetylcholinesterase activity of juvenile largemouth bass Micropterus salmoides by Sublethal concentrations of diazinon. Environmental Research 79, 133 - 137.

Pourgholam R. (2005) Toxicity and immunosuppressive effect of diazinon on grass carp (Ctenopharyngodon idella). $\mathrm{PhD}$ Thesis, University of Putra, Malaysia.

Rahman M.Z., Hossain Z., Mollah M.F.A. \& Ahmad G.U. (2002) Effect of diazinon 60 EC on Anabas testudineus, Channa punctatus and Barbodes gonionotus. The ICLARM Quarterly 25, 8-12.

Roberts R.J. (2001) Fish Pathology, $3^{\text {rd }}$ edn. W.B. Saunders publishing, London, UK.

Sharifpour I., Pourgholam R., Soltani M., Hassan M. D.,
Akbari S. \& Nouri A. (2006) Light and electron microscope of grass carp (Ctenopharyngodon idella) organs following exposure to various sublethal concentrations of diazinon. Iranian Journal of Fisheries Sciences 5, 111 - 136.

Skidermor J.F. \& Tovel P.W.A. (1972) Toxic effects of zinc sulphate on the gills of rainbow trout. Water Research 6, $217-230$. 


\section{مطالعه اثرات سميت غلظت تحت حاد ديازينون بر روى ساختار برخى اندامهاى فيل ماهى (Huso huso)}

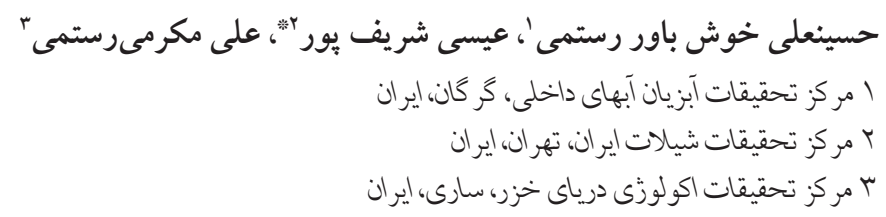

جكيده

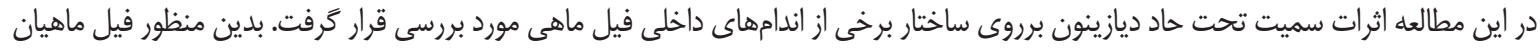

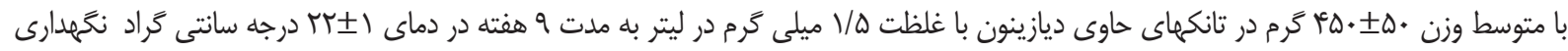

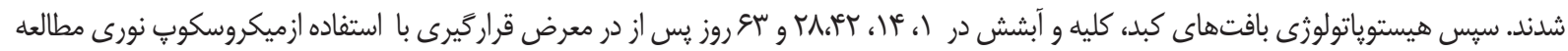

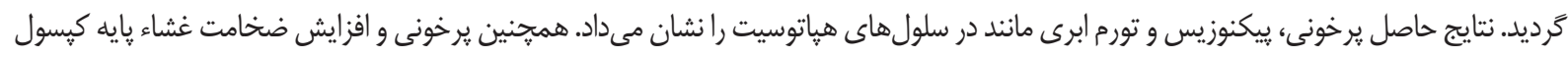

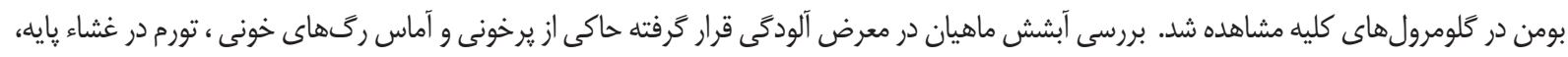

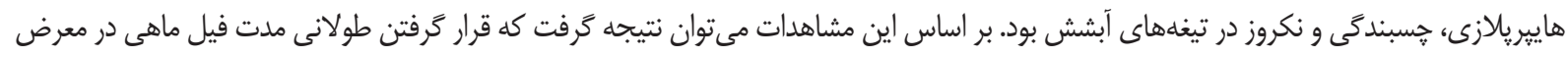

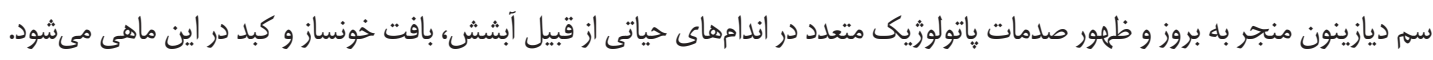
وازههاى كليدى: ديازينون، فيل ماهى، سميت تحت حاد، هيستوياتولوزى. isharifpour@yahoo.com : 